\title{
DAMPAK PENERAPAN STANDAR AKUNTANSI PEMERINTAHAN DAN KOMPETENSI SUMBER DAYA MANUSIA PADA KUALITAS LAPORAN KEUANGAN PEMERINTAH PROVINSI BANTEN TAHUN ANGGARAN 2015
}

\author{
Nikke Yusnita Mahardini \\ nikkeyusnita.m@gmail.com \\ Ade Miranti \\ ademiranti0@gmail.com \\ Universitas Serang Raya
}

\begin{abstract}
ABSTRAK
Penelitian ini bertujuan untuk menguji secara empiris dampak penerapan standar akuntansi pemerintahan dan kompetensi sumber daya manusia pada kualitas laporan keuangan Pemerintah Provinsi Banten. Penelitian ini menggunakan sampel sebanyak 82 responden. Metode pengumpulan data menggunakan kuesioner, sedangkan teknik analisis data yang digunakan adalah uji validitas dan uji reliabilitas dan pengujian hipotesis dengan menggunakan analisis regresi berganda dengan bantuan SPSS 23. Hasil penelitian menunjukkan: (1)penerapan standar akuntansi pemerintahan berpengaruh positif terhadap kualitas laporan keuangan Pemerintah Provinsi Banten Tahun Anggaran 2015. Hal ini membuktikan bahwa semakin baik tingkat penerapan standar akuntansi pemerintahan yang dilakukan dalam penyusunan laporan keuangan, maka akan berdampak positif pada peningkatan kualitas laporan keuangan; (2)kompetensi sumber daya manusia berpengaruh positif terhadap kualitas laporan keuangan Pemerintah Provinsi Banten Tahun Anggaran 2015. Semakin tinggi kompetensi sumber daya manusia yang dimiliki, seperti tingkat pengetahuan, keterampilan dan sikap perilaku dalam melaksanakan tugas dan tanggung jawab maka kualitas laporan keuangan yang dihasilkan cenderung semakin baik.
\end{abstract}

Kata kunci : Penerapan Standar Akuntansi Pemerintahan, Kompetensi Sumber Daya Manusia dan Kualitas Laporan Keuangan.

\section{PENDAHULUAN}

Laporan keuangan adalah produk yang dihasilkan oleh disiplin ilmu akuntansi, sehingga sebagai bentuk pertanggungjawaban, penyajian laporan keuangan harus memenuhi prinsip akuntansi yang berlaku umum dan disajikan secara wajar. Laporan Keuangan Pemerintah Daerah (LKPD) ditujukan untuk memenuhi tujuan umum pelaporan keuangan, serta untuk memenuhi kebutuhan khusus pemakainya. Kualitas LKPD setiap tahunnya akan mendapat penilaian berupa opini dari Badan Pemeriksa Keuangan (BPK). Opini merupakan pernyataan profesional pemeriksa mengenai kewajaran atas laporan keuangan, dimana opini BPK diberikan berdasarkan Peraturan Badan Pemeriksa Keuangan Republik Indonesia Nomor 1 Tahun 2007 tentang Standar Pemeriksaan Keuangan Negara dengan tujuan untuk memberikan pendapat/opini atas kewajaran informasi keuangan yang disajikan dalam laporan keuangan pemerintah daerah dengan mendasarkan pada empat kriteria yaitu: (1)efektivitas sistem pengendalian intern (SPI), (2)ketaatan terhadap perundang-undangan, (3)kecukupan pengungkapan (disclosure), dan (4)kesesuaian dengan standar akuntansi pemerintahan. Terdapat empat opini yang diberikan pemeriksa yaitu : opini Wajar Tanpa Pengecualian (WTP), opini Wajar Dengan Pengecualian (WDP), opini Tidak Wajar (TW), dan Pernyataan Menolak Memberi Opini atau Tidak Memberikan Pendapat (TMP). Ketika BPK meberikan Opini WTP terhadap LKPD, artinya dapat dikatakan bahwa laporan keuangan suatu entitas pemerintah daerah tersebut disajikan dan diungkapkan secara wajar dan berkualitas (Dadang 
Suwanda, 2015). Fenomena dan kenyataan yang terjadi di Pemerintah Provinsi Banten, sejak awal berdiri tahun 2000, LKPD Provinsi Banten selalu mendapat opini Wajar Dengan Pengecualian (WDP) hingga tahun 2012. Bahkan pada tahun anggaran 2013 dan 2014, LKPD Provinsi Banten secara berturut-turut mendapat opini disclaimer dari BPK. Opini BPK atas hasil pemeriksaan LKPD Provinsi Banten Tahun Anggaran 2015 menunjukkan peningkatan dari opini atas LKPD Provinsi Banten Tahun Anggaran 2014 Tidak Memberikan Pendapat (TMP), BPK memberikan opini Wajar Dengan Pengecualian (WDP) untuk LKPD Tahun Anggaran 2015 (BPK RI, 2016). Dalam press release BPK RI Perwakilan Provinsi Banten (2016), saat penyerahan laporan hasil pemeriksaan BPK atas laporan keuangan Pemerintah Provinsi Banten Tahun Anggaran 2015, BPK menilai LKPD Provinsi Banten telah memenuhi kriteria kesesuaian dengan SAP, efektifitas pengendalian intern, kepatuhan terhadap perundang-undangan, serta kecukupan pengungkapan dalam laporan keuangan. Opini laporan keuangan yang diberikan oleh BPK juga mempertimbangkan materialitas penyajian akun antar komponen laporan keuangan dan keseluruhan informasi laporan keuangan. Hal yang dikecualikan dalam opini BPK terhadap LKPD Pemerintah Provinsi Banten Tahun 2015 yaitu : (1)belanja barang dan jasa tahun 2015, diantaranya anggaran belanja uang saku non PNS yang digunakan untuk belanja pegawai honorarium non PNS. Realisasi belanja barang dan jasa pada Satuan Polisi Pamong Praja (Satpol PP) yang pembayarannya dengan uang persediaan dipertanggungjawabkan tidak sesuai dengan pengeluaran uang yang sesungguhnya. Realisasi belanja promosi dan publikasi terdapat kelebihan pembayaran yang telah diungkapkan dalam Laporan BPK atas pemeriksaan belanja daerah Tahun Anggaran 2015 pada Pemerintah Provinsi Banten; (2)Aset Peralatan dan Mesin, diantaranya terdapat kendaraan bermotor dinas yang dikuasai pihak ketiga dan yang tidak dapat ditelusuri. BPK tidak memungkinkan menerapkan prosedur pemeriksaan karena ketidakcukupan catatan akuntansi; (3) Akumulasi penyusutan Aset Tetap per 31 Desember 2015 diantaranya terdapat nilai penyusutan untuk aset Gedung dan Bangunan serta Jalan, Irigasi dan Jaringan belum diyakini kewajarannya. Dokumen dan catatan yang tersedia tidak memungkinkan BPK untuk menerapkan prosedur pemeriksaan yang memadai.

Dalam kaitannya dengan kualitas laporan keuangan yang menjadi masalah penelitian skripsi ini, berdasarkan penilaian BPK diketahui bahwa laporan keuangan Pemerintah Provinsi Banten walaupun mengalami peningkatan kualitas dari tahun sebelumnya tapi masih kurang baik, indikasinya masih terdapat pengecualian terkait penganggaran belanja barang jasa yang digunakan tidak sesuai dengan pengeluaran uang yang sesungguhnya, ketidakcukupan catatan akuntansi pada aset peralatan dan mesin serta akumulasi penyusutan aset tetap per 31 Desember 2015 masih terdapat terdapat nilai penyusutan untuk aset Gedung dan Bangunan serta Jalan, Irigasi dan Jaringan belum diyakini kewajarannya, ini berarti laporan keuangan Pemerintah Provinsi Banten Tahun 2015 kurang memenuhi karakteristik andal, dimana seharusnya informasi dalam laporan keuangan bebas dari pengertian yang menyesatkan dan kesalahan material, menyajikan setiap fakta secara, jujur, serta dapat diverifikasi. Informasi mungkin relevan, tetapi jika hakikat atau penyajiannya tidak dapat diandalkan maka penggunaan informasi tersebut secara potensial dapat menyesatkan. Lemahnya penerapan Standar Akuntansi Pemerintahan (SAP) dan kurangnya kompetensi Sumber Daya Manusia (SDM) yang belum optimal diduga sebagai faktor penyebab tidak tercapainya opini WTP seperti yang ditargetkan Pemerintah Provinsi Banten. Oleh karena itu, topik penelitian mengenai kualitas laporan keuangan sangat menarik untuk dikaji lebih jauh pada Pemerintah Provinsi Banten. Hal ini karena pada tahun anggaran 2015 Pemerintah Provinsi Banten mulai menerapkan standar akuntansi pemerintahan berbasis akrual. Perubahan kebijakan ini secara tidak langsung mempengaruhi pelaksanaan penerapan standar akuntansi pemerintahan yang selama ini digunakan dalam penyusunan laporan keuangan. Selain itu, faktor kompetensi sumber daya manusia yang terlibat langsung dalam penerapan 
standar akuntansi pemerintahan tersebut juga menarik untuk diteliti pengaruhnya terhadap kualitas laporan keuangan Pemerintah Provinsi Banten. Perubahan basis akuntansi dari akuntansi berbasis kas menjadi akuntansi berbasis akrual memerlukan proses penyesuaian yang perlu dipahami oleh seluruh unsur sumber daya manusia pelaksana akuntansi di pemerintah daerah dimana hal ini bukan sekedar masalah pencatatan transaksi dan penyajian laporan keuangan, tetapi membutuhkan pemahaman kebijakan akuntansi, sistem dan prosedur akuntansi yang menjabarkan secara jelas perlakuan akuntansi untuk suatu transaksi, pengukuran akuntansi serta menganalisis transaksi dan sistem akuntansi dimana hal ini secara umum telah dijelaskan dalam PSAP.

\section{TINJAUAN PUSTAKA}

\section{Standar Akuntansi Pemerintahan}

Akuntansi adalah proses identifikasi, pencatatan, pengukuran, pengklasifikasian, pengikhtisaran transaksi dan kejadian keuangan, penyajian laporan, serta penginterpretasian atas hasilnya. Standar akuntansi sangat penting sebagai pedoman untuk pembuat laporan keuangan dan sebagai salah satu mekanisme pengendalian. Tidak adanya standar akuntansi yang memadai akan menimbulkan implikasi negatif berupa rendahnya reliabilitas informasi keuangan serta menyulitkan dalam pengendalian (Mardiasmo, 2009). Standar Akuntansi Pemerintahan menurut Peraturan Pemerintah Nomor 71 Tahun 2010 tentang Standar Akuntansi Pemerintahan dalam Pasal 1 angka 3 disebutkan Standar Akuntansi Pemerintahan, yang selanjutnya disingkat SAP adalah prinsip-prinsip akuntansi yang diterapkan dalam menyusun dan menyajikan laporan keuangan pemerintah. Dalam Ketentuan Penutup Peraturan Pemerintah Nomor 71 Tahun 2010 tentang Standar Akuntansi Pemerintahan disebutkan bahwa pada saat Peraturan Pemerintah ini mulai berlaku maka Peraturan Pemerintah Nomor 24 Tahun 2005 dicabut dan dinyatakan tidak berlaku. Penerapan SAP Berbasis Akrual sebagaimana dimaksud dalam Pemerintah Nomor 71 Tahun 2010 pasal 4 ayat (1) dapat dilaksanakan secara bertahap dari penerapan SAP Berbasis Kas Menuju Akrual menjadi penerapan SAP Berbasis Akrual. Laporan keuangan yang dihasilkan dari penerapan SAP berbasis akrual dimaksudkan untuk memberi manfaat lebih baik bagi para pemangku kepentingan, baik para pengguna maupun pemeriksa laporan keuangan pemerintah, dibandingkan dengan biaya yang dikeluarkan. Hal ini sejalan dengan salah satu prinsip akuntansi yaitu bahwa biaya yang dikeluarkan sebanding dengan manfaat yang diperoleh.

Undang-Undang Nomor 17 Tahun 2003 tentang Keuangan Negara dalam Pasal 32 mengamanatkan bahwa bentuk dan isi laporan pertanggungjawaban pelaksanaan Anggaran Pendapatan Belanja Negara (APBN) / Anggaran Pendapatan Belanja Daerah (APBD) disusun dan disajikan sesuai dengan Standar Akuntansi Pemerintahan. Standar akuntansi pemerintahan tersebut disusun oleh Komite Standar Akuntansi Pemerintahan yang independen dan ditetapkan dengan Peraturan Pemerintah setelah terlebih dahulu mendapat pertimbangan dari Badan Pemeriksa Keuangan. Sesuai dengan amanat Undang-Undang Keuangan Negara tersebut, Pemerintah telah menetapkan Peraturan Pemerintah Nomor 24 Tahun 2005 tentang Standar Akuntansi Pemerintahan. Standar Akuntansi Pemerintahan tersebut menggunakan basis kas untuk pengakuan transaksi pendapatan, belanja dan pembiayaan, dan basis akrual untuk pengakuan aset, kewajiban, dan ekuitas dana. Penerapan Peraturan Pemerintah Nomor 24 Tahun 2005 masih bersifat sementara sebagaimana diamanatkan dalam Pasal 36 ayat (1) Undang-Undang Nomor 17 Tahun 2003 tentang Keuangan Negara yang menyatakan bahwa selama pengakuan dan pengukuran pendapatan dan belanja berbasis akrual belum dilaksanakan, digunakan pengakuan dan pengukuran berbasis kas. Pengakuan dan pengukuran pendapatan dan belanja berbasis akrual menurut Pasal 36 ayat (1) Undang-Undang Nomor 17 Tahun 2003 dilaksanakan paling lambat 5 (lima) tahun yaitu pada Tahun 2015. SAP Basis kas adalah SAP yang mengakui pengaruh transaksi 
dan peristiwa lainnya pada saat kas atau setara kas diterima atau dibayar. SAP Berbasis Kas Menuju Akrual adalah SAP yang mengakui pendapatan, belanja, dan pembiayaan berbasis kas, serta mengakui aset, utang, dan ekuitas dana berbasis akrual. SAP Berbasis Akrual adalah SAP yang mengakui pendapatan, beban, aset, utang, dan ekuitas dalam pelaporan finansial berbasis akrual, serta mengakui pendapatan, belanja, dan pembiayaan dalam pelaporan pelaksanaan anggaran berdasarkan basis yang ditetapkan dalam APBN/APBD.

\section{Pernyataan Standar Akuntansi Pemerintahan}

Pernyataan Standar Akuntansi Pemerintahan, yang selanjutnya disingkat PSAP, adalah SAP yang diberi judul, nomor, dan tanggal efektif, sebagai berikut :

1. PSAP 01 Penyajian Laporan Keuangan

Tujuan pernyataan standar ini adalah mengatur penyajian laporan keuangan untuk tujuan umum (general purpose financial statements) dalam rangka meningkatkan keterbandingan laporan keuangan baik terhadap anggaran, antar periode, maupun antar entitas. Entitas pelaporan menyelenggarakan akuntansi dan penyajian laporan keuangan dengan menggunakan basis akrual baik dalam pengakuan pendapatan dan beban, maupun pengakuan aset, kewajiban, dan ekuitas. Entitas pelaporan yang menyelenggarakan akuntansi berbasis akrual, menyajikan Laporan Realisasi Anggaran berdasarkan basis yang ditetapkan dalam peraturan perundang-undangan tentang anggaran.

2. PSAP 02 Laporan Realisasi Anggaran Berbasis Kas

Tujuan standar Laporan Realisasi Anggaran adalah menetapkan dasar-dasar penyajian Laporan Realisasi Anggaran untuk pemerintah dalam rangka memenuhi tujuan akuntabilitas sebagaimana ditetapkan oleh peraturan perundang-undangan. Pernyataan standar ini diterapkan dalam penyajian Laporan Realisasi Anggaran yang disusun dan disajikan dengan menggunakan anggaran berbasis kas.

3. PSAP 03 Laporan Arus Kas

Tujuan Pernyataan Standar Laporan Arus Kas adalah mengatur penyajian laporan arus kas yang memberikan informasi historis mengenai perubahan kas dan setara kas suatu entitas pelaporan dengan mengklasifikasikan arus kas berdasarkan aktivitas operasi, investasi, pendanaan, dan transitoris selama satu periode akuntansi.

4. PSAP 04 Catatan Atas Laporan Keuangan

Tujuan Pernyataan Standar Catatan atas Laporan Keuangan adalah mengatur penyajian dan pengungkapan yang diperlukan pada Catatan atas Laporan Keuangan. Tujuan penyajian Catatan atas Laporan Keuangan adalah untuk meningkatkan transparansi Laporan Keuangan dan penyediaan pemahaman yang lebih baik, atas informasi keuangan pemerintah.

5. PSAP 05 Akuntansi Persedian

Tujuan Pernyataan Standar ini adalah untuk mengatur perlakuan akuntansi persediaan yang dianggap perlu disajikan dalam laporan keuangan. Persediaan diakui (a) pada saat potensi manfaat ekonomi masa depan diperoleh pemerintah dan mempunyai nilai atau biaya yang dapat diukur dengan andal, (b) pada saat diterima atau hak kepemilikannya dan/ atau kepenguasaannya berpindah. Pada akhir periode akuntansi catatan persediaan disesuaikan dengan hasil inventarisasi fisik.

6. PSAP 06 Akuntansi Investasi

Tujuan Pernyataan Standar ini adalah untuk mengatur perlakuan akuntansi untuk investasi dan pengungkapan informasi penting lainnya yang harus disajikan dalam laporan keuangan.

7. PSAP 07 Akuntansi Aset Tetap 
Tujuan Pernyataan Standar ini adalah mengatur perlakuan akuntansi untuk aset tetap meliputi pengakuan, penentuan nilai tercatat, serta penentuan dan perlakuan akuntansi atas penilaian kembali dan penurunan nilai tercatat (carrying value) aset tetap.

8. PSAP 08 Akuntansi Konstruksi Dalam Pengerjaan

Tujuan Pernyataan Standar Konstruksi Dalam Pengerjaan adalah mengatur perlakuan akuntansi untuk konstruksi dalam pengerjaan.

9. PSAP 09 Akuntansi Kewajiban

Tujuan Pernyataan Standar ini adalah mengatur perlakuan akuntansi kewajiban meliputi saat pengakuan, penentuan nilai tercatat, amortisasi, dan biaya pinjaman yang dibebankan terhadap kewajiban tersebut.

10. PSAP 10 Koreksi Kesalahan, Perubahan Estimasi Akuntansi, dan Operasi Yang Tidak Dilanjutkan

Tujuan Pernyataan Standar ini adalah mengatur perlakuan akuntansi atas koreksi

kesalahan akuntansi dan pelaporan laporan keuangan, perubahan kebijakan akuntansi, perubahan estimasi akuntansi, dan operasi yang tidak dilanjutkan

11. PSAP 11 Laporan Keuangan Konsolidasian

Tujuan Pernyataan Standar ini adalah untuk mengatur penyusunan laporan keuangan konsolidasian pada unit-unit pemerintahan dalam rangka menyajikan laporan keuangan untuk tujuan umum (general purpose financial statements) demi meningkatkan kualitas dan kelengkapan laporan keuangan dimaksud.

12. PSAP 12 Laporan Operasional

Tujuan pernyataan standar Laporan Operasional adalah menetapkan dasar-dasar penyajian Laporan Operasional untuk pemerintah dalam rangka memenuhi tujuan akuntabilitas penyelenggaraan pemerintahan sebagaimana ditetapkan oleh peraturan perundangundangan. Tujuan pelaporan operasi adalah memberikan informasi tentang kegiatan operasional keuangan yang tercerminkan dalam pendapatan-LO, beban, dan surplus/defisit operasional dari suatu entitas pelaporan.

13. PSAP ini berlaku efektif untuk laporan keuangan atas pertanggungjawaban pelaksanaan anggaran mulai Tahun Anggaran 2010. Dalam hal entitas pelaporan belum dapat menerapkan PSAP ini, entitas pelaporan dapat menerapkan PSAP berbasis kas menuju akrual paling lama 4 (empat) tahun setelah Tahun Anggaran 2010.

\section{Basis Akuntansi}

Basis akuntansi yang digunakan dalam laporan keuangan pemerintah adalah basis akrual, untuk pengakuan pendapatan-LO, beban, aset, kewajiban, dan ekuitas. Basis akrual untuk LO berarti bahwa pendapatan diakui pada saat hak untuk memperoleh pendapatan telah terpenuhi walaupun kas belum diterima di Rekening Kas Umum Negara/Daerah atau oleh entitas pelaporan dan beban diakui pada saat kewajiban yang mengakibatkan penurunan nilai kekayaan bersih telah terpenuhi walaupun kas belum dikeluarkan dari Rekening Kas UmumNegara/Daerah atau entitas pelaporan. Pendapatan seperti bantuan pihak luar/asing dalam bentuk jasa disajikan pula pada LO.

\section{Kompetensi Sumber Daya Manusia}

Moeheriono (2009) mendefinisikan kompetensi adalah sebagai berikut : "kompetensi merupakan sebuah karakteristik dasar seseorang yang mengindikasikan cara berpikir, bersikap, dan bertindak serta menarik kesimpulan yang dapat dilakukan dan dipertahankan oleh seseorang pada waktu periode tertentu". Seseorang yang memiliki kompetensi akan bekerja dengan pengetahuan dan keterampilannya sehingga dapat bekerja dengan mudah, cepat, intuitif dan dengan pengalamannya bisa meminimalisir kesalahan. 
Sumber daya manusia merupakan salah satu elemen organisasi yang sangat penting, oleh karena itu harus dipastikan bahwa pengelolaan sumber daya manusia dilakukan sebaik mungkin agar mampu memberikan kontribusi secara optimal dalam upaya pencapaian tujuan organisasi.

\section{Laporan Keuangan Pemerintah Daerah}

Laporan keuangan menurut Ikatan Akuntan Indonesia melalui "Standar Akuntansi Keuangan" (2012) merupakan bagian dari proses pelaporan. Laporan keuangan yang lengkap, biasanya meliputi neraca, laporan laba-rugi, laporan perubahan posisi keuangan (yang disajikan dengan berbagai cara seperti laporan arus kas atau laporan arus dana), catatan atau laporan lain serta materi penjelasan yang merupakanbagian integral dari laporan keuangan. Disamping itu juga termasuk skedul dan informasi tambahan yang berkaitan dengan laporan tersebut, misalnya informasi keuangan, segmen industri dan geografis serta pengungkapan pengaruh perubahan harga".

\section{Kualitas Laporan Keuangan}

Kriteria dan unsur-unsur pembentuk kualitas laporan keuangan yang menjadikan informasi dalam laporan keuangan pemerintah mempunyai nilai atau manfaat terdiri dari relevan, andal, dapat dibandingkan, dan dapat dipahami. Keempat karakteristik ini merupakan prasyarat normatif yang mutlak diperlukan agar laporan keuangan pemerintah dapat memenuhi kualitas yang dikehendaki.

dimengerti.

\section{Pengembagan Hipotesis}

H1 : Penerapan standar akuntansi pemerintahan berpengaruh terhadap kualitas Laporan Keuangan Pemerintah Provinsi Banten Tahun Anggaran 2015.

H2 : Kompetensi sumber daya manusia berpengaruh terhadap kualitas Laporan Keuangan Pemerintah Provinsi Banten Tahun Anggaran 2015.

H3 : Penerapan standar akuntansi pemerintahan dan kompetensi sumber daya manusia secara bersama berpengaruh terhadap kualitas laporan keuangan Pemerintah Provinsi Banten Tahun Anggaran 2015.

\section{METODE PENELITIAN}

\section{Metode Penelitian}

Penelitian ini menggunakan metode penelitian kuantitatif. Objek penelitian adalah penerapan standar akuntansi pemerintahan yang disebut sebagai variabel X1, kompetensi sumber daya manusia yang disebut sebagai variabel $\mathrm{X} 2$, dan kualitas laporan keuangan pemerintah Provinsi Banten Tahun Anggaran 2015 sebagai variabel Y. Model desain yang digunakan adalah penelitian eksplanatori yaitu penelitian yang dilakukan untuk memperoleh deskripsi, gambaran atau lukisan secara sistematis, faktual dan akurat mengenai fakta-fakta, sifat-sifat serta hubungan antar variabel yang diteliti. Penelitian ini menggunakan data primer. Data primer diperoleh dari instrumen penelitian berupa kuesioner. Instrumen penelitian dalam penelitian ini adalah kuesioner yang terdiri dari dua bagian. Bagian pertama dari kuesioner ini berisi pertanyaan mengenai identitas responden yang menanyakan mengenai nama, usia, jenis kelamin, pekerjaan/jabatan, pendidikan dan unit kerja. Bagian kedua dari kuesioner berisi pernyataan mengenai persepsi responden mengenai penerapan SAP, kompetensi SDM pengelola keuangan dan pernyataan tentang karakteristik kualitatif laporan keuangan. Populasi sasaran yang penulis teliti adalah subjek yang berhubungan dengan penerapan SAP dan kompetensi SDM dalam kaitan pengaruhnya terhadap kualitas laporan keuangan pemerintah daerah meliputi 41 Perangkat Daerah di Lingkungan Pemerintah Provinsi Banten 
(Peraturan Daerah Provinsi Banten Nomor 8 Tahun 2016 tentang Pembentukan dan Susunan Perangkat Daerah Provinsi Banten). Teknik pengambilan sampel yang digunakan adalah purposive sampling.

\section{HASIL PENELITIAN DAN PEMBAHASAN \\ Hasil Uji Validitas}

Suatu kuesioner dikatakan valid jika nilai korelasi ( $\mathrm{r}$ hitung) $>\mathrm{r}$ tabel. Dalam hal ini $\mathrm{r}$ tabel dapat dilihat pada tabel $r$ statistik dengan menghitung terlebih dahulu : $\mathrm{df}=\mathrm{n}-2(\mathrm{n}=$ jumlah responden). $\mathrm{df}=\mathrm{n}-2=82-2=80$ dengan taraf signifikan 5\% Jadi, dengan jumlah responden 82 dan taraf signifikansi $5 \%$, maka didapat nilai $\mathrm{r}$ tabel sebesar 0,1829 (sumber : tabel r) Dari hasil olah data dengan SPSS 23 diperoleh data valid sebanyak 82 item.

\section{Hasil Uji Reliabilitas}

Berdasarkan pengujian reliabilitas diperoleh hasil yang menunjukkan bahwa tingkat besaran alpha dari masing-masing variabel lebih besar dari nilai koefisien alat uji yang digunakan maka semua variabel pertanyaan yang digunakan dalam penelitian ini adalah andal (reliabel). Dari hasil olah data dengan SPSS 23, penelitian menunjukkan bahwasanya variabel $\mathrm{X} 1, \mathrm{X} 2$, dan Y memiliki nilai koefisien alpha cronbach's diatas 0,6 sehingga terbukti reliable.

\section{Pengujian Hipotesis}

\section{Hasil Analisis Regresi Berganda}

Konsep dasar analisis regresi berganda adalah untuk mengetahui ada atau tidaknya pengaruh dua atau lebih variabel bebas ( X1 dan X2) terhadap variabel terikat (Y).

Berdasarkan pada hasil perhitungan dari model regresi linier berganda, diperoleh hasil persamaan regresi yang dapat dilihat sebagai berikut ini :

\section{Tabel Hasil Perhitungan Regresi Linier Berganda}

\section{Coefficients $^{\mathrm{a}}$}

\begin{tabular}{|c|c|c|c|c|c|c|}
\hline \multirow{2}{*}{\multicolumn{2}{|c|}{ Model }} & \multicolumn{2}{|c|}{$\begin{array}{c}\text { Unstandardized } \\
\text { Coefficients }\end{array}$} & \multirow{2}{*}{$\begin{array}{c}\text { Standardized } \\
\text { Coefficients } \\
\text { Beta }\end{array}$} & \multirow[b]{2}{*}{$\mathrm{T}$} & \multirow[b]{2}{*}{ Sig. } \\
\hline & & B & Std. Error & & & \\
\hline \multirow[t]{3}{*}{1} & (Constant & -3.112 & 5.633 & & -.552 & .582 \\
\hline & $\mathrm{X} 1$ & .620 & .136 & .406 & 4.570 & .000 \\
\hline & $\mathrm{X} 2$ & .810 & .168 & .430 & 4.830 & .000 \\
\hline
\end{tabular}

\section{Sumber: Data Primer Diolah}

Dari tabel dapat diketahui bahwa persamaan regresi yang dihasilkan adalah sebagai berikut: Rumus regresi yang digunakan adalah:

$\mathrm{Y}=-3,112+0,620 \mathrm{X} 1+0,810 \mathrm{X} 2+\mathrm{e}$

\section{Hasil Uji t (Parsial)}

\section{Coefficients $^{\mathrm{a}}$}

\begin{tabular}{cccccc}
\hline & \multicolumn{4}{c}{ Unstandardized Coefficients } & \multicolumn{2}{c}{ Standardized } \\
Coefficients & & \\
Model & B & Std. Error & Beta & t & Sig. \\
\hline
\end{tabular}




\begin{tabular}{crrrrr}
\hline 1 (Constant) & -3.112 & 5.633 & & -.552 & .582 \\
$\mathrm{X} 1$ & .620 & .136 & .406 & 4.570 & .000 \\
$\mathrm{X} 2$ & .810 & .168 & .430 & 4.830 & .000 \\
\hline
\end{tabular}

a. Dependent Variable: Y

Berdasarkan hasil uji di atas menunjukkan hasil bahwa secara parsial variabel penerapan standar akuntansi pemerintahan berpengaruh terhadap kualitas laporan keuangan Pemerintah Provinsi Banten. Dan variabel kompetensi sumber daya manusia berpengaruh terhadap kualitas laporan keuangan Pemerintah Provinsi Banten.

Hasil Uji F (Simultan)

Tabel Perhitungan Uji F

ANOVA $^{b}$

\begin{tabular}{llrrrrr}
\hline Model & & Sum of Squares & Df & Mean Square & F & \multicolumn{1}{c}{ Sig. } \\
\hline 1 & Regression & 700.492 & 2 & 350.246 & 41.892 & $.000^{\mathrm{a}}$ \\
& Residual & 660.496 & 79 & 8.361 & & \\
& Total & 1360.988 & 81 & & & \\
\hline
\end{tabular}

a. Predictors: (Constant), X2,X1

b. Dependent Variable: Y

Berdasarkan output SPSS 23 diatas diketahui nilai signifikansi untuk pengaruh X1 dan X2 secara simultan terhadap $\mathrm{Y}$ adalah $0,000<0,05$ dan nilai $\mathrm{F}$ hitung 41,892 > F tabel 3,15 sehingga dapat disimpulkan bahwa $\mathrm{H} 3$ diterima yang berarti terdapat pengaruh $\mathrm{X} 1$ dan $\mathrm{X} 2$ secara bersama-sama terhadap Y.

\section{Hasil Analisa Koefisien Determinasi}

Koefisien Korelasi (R) dan Koefisien Determinasi $\left(\mathrm{R}^{2}\right)$ berdasarkan output olah data SPSS 23 dibawah ini diketahui Adjusted $\mathrm{R}$ Square sebesar 0,502, hal ini mengandung arti bahwa pengaruh variabel X1 dan X2 secara simultan terhadap variabel Y adalah sebesar 50,2\%.

\begin{tabular}{|c|c|c|c|c|c|}
\hline \multicolumn{6}{|c|}{ Model Summary $^{\mathbf{b}}$} \\
\hline Model & $\mathrm{R}$ & R Square & $\begin{array}{c}\text { Adjusted R } \\
\text { Square }\end{array}$ & $\begin{array}{l}\text { Std. Error of the } \\
\text { Estimate }\end{array}$ & Durbin-Watson \\
\hline 1 & $.717^{\mathrm{a}}$ & .515 & .502 & 2.89149 & 1.846 \\
\hline
\end{tabular}

a. Predictors: (Constant), X2, X1

b. Dependent Variable: Y

Dari tabel diatas diketahui bahwa nilai koefisien korelasi berganda (R), yaitu korelasi antara dua atau lebih variabel independen penerapan standar akuntansi pemerintahan (X1) dan kompetensi sumber daya manusia (X2) terhadap variabel dependen (kualitas laporan keuangan Pemerintah Provinsi Banten (Y)) sebesar 0,717. Hal ini berarti terdapat hubungan yang kuat. Nilai koefisien determinasi berganda adalah 0,502 $(\mathrm{Kd}=0.502 \times 100 \%)$ atau $50,2 \%$ nilai ini menunjukkan bahwa hanya sebesar 50,2\% kualitas laporan keuangan Pemerintah Provinsi Banten (Y) dipengaruhi oleh penerapan standar akuntansi pemerintahan (X1) dan kompetensi sumber daya manusia (X2) sedangkan sisanya sisanya 49,8\% dipengaruhi oleh variabel lain diluar penelitian. 


\section{Pembahasan}

Berdasarkan hasil uji hipotesis secara statistik yang telah dilaksanakan, diperoleh pembahasan deskriptif yang menjelaskan hasil uji empiris dibandingkan dengan teori yang dikemukakan pada bab sebelumnya, dan perbandingan terhadap hasil-hasil penelitian sebelumnya. Hasil pengujian hipotesis penerapan standar akuntansi pemerintahan mempunyai nilai signifikansi $0,000<0,05$ maka $\mathrm{H} 0$ ditolak dan $\mathrm{H} 1$ diterima. Hal ini menunjukkan bahwa secara parsial variabel penerapan standar akuntansi pemerintahan (X1) berpengaruh terhadap Kualitas Laporan Keuangan Pemerintah Provinsi Banten Tahun Anggaran 2015 (Y). Adapun arah pengaruh dari penerapan standar akuntansi pemerintahan terhadap kualitas laporan keuangan Pemerintah Provinsi Banten Tahun Anggaran 2015 adalah positif yang menunjukkan semakin tinggi penerapan standar akuntansi pemerintahan maka akan semakin baik pula kualitas laporan keuangan Pemerintah Provinsi Banten. Penerapan standar akuntansi pemerintahan berpengaruh secara signifikan terhadap kualitas laporan keuangan Pemerintah Provinsi Banten Tahun Anggaran 2015. Hasil penelitian ini mendukung data hasil pemeriksaan BPK atas laporan keuangan Pemerintah Provinsi Banten Tahun Anggaran 2015 yang berdasarkan Peraturan Badan Pemeriksa Keuangan Republik Indonesia Nomor 1 Tahun 2007 tentang Standar Pemeriksaan Keuangan Negara, salah satu kriteria yang harus dipenuhi dalam penyajian laporan keuangan pemerintah daerah adalah kesesuaian dengan standar akuntansi pemerintahan. Fenomena peningkatan opini BPK atas pemeriksaan laporan keuangan Pemerintahan Provinsi Banten dari opini LKPD Provinsi Banten Tahun Anggaran 2014 memperoleh opini Tidak Memberikan Pendapat (TMP) menjadi opini Wajar Dengan Pengecualian (WDP) pada LKPD Provinsi Banten Tahun Anggaran 2015 terjawab dengan semakin membaiknya penerapan standar akuntansi pemerintahan. Dengan penerapan standar akuntansi yang baik dalam penyusunan dan penyajian laporan keuangan di lingkungan Pemerintah Provinsi Banten dapat meningkatkan kualitas laporan keuangan. Hasil penelitian ini mendukung hasil penelitian Rukmi Juwita (2013) yang menyatakan pengujian regresi secara parsial dengan uji t maupun secara simultan dengan uji F, bahwa implementasi standar akuntansi pemerintahan dan implementasi sistem informasi akuntansi berpengaruh secara signifikan terhadap kualitas laporan keuangan.

Hasil analisis hipotesis kompetensi sumber daya manusia mempunyai nilai signifikansi 0,000 $<0,05$ maka $\mathrm{H} 0$ ditolak dan $\mathrm{H} 2$ diterima. Hal ini menunjukkan bahwa secara parsial variabel kompetensi sumber daya manusia (X2) berpengaruh terhadap kualitas laporan keuangan Pemerintah Provinsi Banten Tahun Anggaran 2015 (Y). Kualitas pelaporan keuangan akan semakin baik apabila didukung oleh sumber daya manusia yang kompeten, seperti yang telah dijelaskan dalam kajian pustaka bahwa seseorang yang memiliki kompetensi akan bekerja dengan pengetahuan dan keterampilannya sehingga dapat bekerja dengan mudah, cepat, intuitif dan dengan pengalamannya untuk meminimalisir kesalahan. Hasil penelitian ini mendukung hasil penelitian Devi Roviyantie (2012) yang menyatakan bahwa bahwa pengujian regresi secara parsial dengan uji t maupun secara simultan dengan uji F, memperlihatkan kompetensi SDM dan penerapan sistem akuntansi keuangan berpengaruh signifikan terhadap kualitas laporan keuangan daerah.

Hasil analisis Uji F diperoleh nilai signifikansi 0,000 < 0,05 maka H0 ditolak dan H3 diterima. Hal ini menunjukkan bahwa penerapan standar akuntansi pemerintahan (X1) dan kompetensi sumber daya manusia (X2) secara serentak atau bersama-sama berpengaruh terhadap kualitas laporan keuangan Pemerintah Provinsi Banten Tahun Anggaran 2015 (Y). Ini berarti semakin tinggi penerapan standar akuntansi pemerintahan dan kompetensi sumber daya manusia maka akan semakin baik pula kualitas laporan keuangan Pemerintah Provinsi Banten. Hasil penelitian ini mendukung penelitian Kadek Desiana Wati, dkk (2014) yang menyatakan bahwa kompetensi SDM berpengaruh positif dan signifikan terhadap kualitas 
laporan keuangan daerah, penerapan SAP berpengaruh positif dan signifikan terhadap kualitas laporan keuangan daerah, SAKD berpengaruh positif dan signifikan terhadap kualitas laporan keuangan daerah, dan kompetensi sumber daya manusia, penerapan standar akuntansi pemerintahan, sistem akuntansi keuangan daerah secara simultan berpengaruh signifikan terhadap kualitas laporan keuangan.

\section{KESIMPULAN DAN SARAN}

Penelitian ini bertujuan untuk menyediakan bukti-bukti empiris mengenai pengaruh penerapan standar akuntansi pemerintahan dan pengaruh kompetensi sumber daya manusia terhadap kualitas laporan keuangan Pemerintah Provinsi Banten Tahun Anggaran 2015. Berdasarkan hasil analisis data sebagaimana telah dibahas pada bab sebelumnya, maka dapat ditarik kesimpulan: Secara parsial penerapan standar akuntansi pemerintahan berpengaruh positif terhadap kualitas laporan keuangan Pemerintah Provinsi Banten Tahun Anggaran 2015. Ketika standar akuntansi pemerintahan diterapkan dengan baik, maka akan semakin baik pula kualitas laporan keuangan yang dihasilkan. Secara parsial kompetensi sumber daya manusia berpengaruh positif terhadap kualitas laporan keuangan Pemerintah Provinsi Banten Tahun Anggaran 2015, artinya bahwa semakin kompeten sumber daya manusia pembuat laporan keuangan, maka semakin baik pula kualitas laporan keuangan yang dihasilkan. Penerapan standar akuntansi pemerintahan dan kompetensi sumber daya manusia secara bersama-sama (simultan) berpengaruh positif terhadap kualitas laporan keuangan Pemerintah Provinsi Banten Tahun Anggaran 2015. Hal ini menunjukan bahwa peningkatan kualitas laporan keuangan Pemerintah Provinsi Banten Tahun Anggaran 2015 dipengaruhi oleh kompetensi sumber daya manusia pengelola keuangan/akuntansi dan penerapan standar akuntansi pemerintahan yang baik.

Dengan pertimbangan pada keterbatasan yang ada dalam penelitian ini, maka disarankan hal-hal sebagai berikut : Bagi Pemerintah Daerah, setiap perangkat daerah terutama sumber daya manusia yang terlibat langsung dalam penyusunan laporan keuangan dapat menerapkan standar akuntansi pemerintahan yang berlaku guna menghasilkan laporan keuangan yang berkualitas, disamping itu masih perlu ditingkatkan sumber daya manusia yang memiliki pengetahuan di bidang akuntansi dan pengelolaan keuangan serta mengikutsertakan pegawai dalam pendidikan dan pelatihan serta sosialisasi peraturan tentang akuntansi pemerintahan. Bagi pihak lain, sebagai bahan referensi bagi calon peneliti berikutnya khususnya yang berminat melakukan penelitian mengenai faktor-faktor yang mempengaruhi kualitas laporan keuangan pemerintah daerah agar hasilnya bisa lebih baik dan akurat disarankan untuk menambah variabel-variabel penelitian seperti sistem pengendalian intern pemerintah, komitmen, pemanfaatan teknologi dan sistem informasi manajemen keuangan daerah.

\section{DAFTAR PUSTAKA}

Halim, Abdul dan Syam Kusufi, Muhammad. (2014). Akuntansi Sektor Publik : Akuntansi Keuangan Daerah - SAP Berbasis Akrual. Edisi 4. Jakarta : Penerbit Salemba Empat

Humairoh, Iftitah Dian. (2013). Pengaruh Kompetensi Sumber Daya Manusia (SDM) Terhadap Kualitas Laporan Keuangan Pemerintah Daerah (Studi Empiris pada SKPD Kabupaten Jember), Artikel Ilmiah Mahasiswa, Akuntansi, Fakultas Ekonomi, Universitas Jember (UNEJ), Jember

Ihsanti, Emilda. (2014). Pengaruh Kompetensi Sumber Daya Manusia dan Penerapan Sistem Akuntansi Keuangan Daerah Terhadap Kualitas Laporan Keuangan Daerah (Studi Empiris pada SKPD Kab.Lima Puluh Kota), Artikel, Program Studi Akuntansi Fakultas Ekonomi, Universitas Negeri Padang, Dipublikasikan.

Ikatan Akuntan Indonesia. (2012). Standar Akuntansi Keuangan, Jakarta : Gramedia. 
Juwita, Rukmi. (2013). Pengaruh Implementasi Standar Akuntansi Pemerintahan dan Sistem Informasi Akuntansi Terhadap Kualitas Laporan Keuangan, Jurnal Trikonomika, Volume 12 No.2, Politeknik Pos Indonesia, Bandung

Kadek Desiana Wati, Nyoman Trisna Herawati, Ni Kadek Sinarwati. (2014). Pengaruh Kompetensi SDM, Penerapan SAP, dan Sistem Akuntansi Keuangan Daerah Terhadap Kualitas Laporan Keuangan Daerah, e-Journal S1 Ak Universitas Pendidikan Ganesha, Volume 2 No.1, Singaraja, Indonesia

Mahmudin, Eka. (2017). Pengaruh Kompetensi Akuntan Internal, Sistem Pengendalian Internal dan Manajemen Aset Terhadap Kualitas Pelaporan Keuangan dan Dampaknya Terhadap Akuntabilitas Keuangan, The Student of Accounting Magister Program Sultan Ageng Tirtayasa University, Serang, Indonesia

Moehirono. (2009). Pengaruh Kinerja Berbasis Kompetensi. Surabaya : Ghalia Indonesia.

Ni Made Sudiarianti, dkk (2015), Pengaruh Kompetensi Sumber Daya Manusia Pada Penerapan Sistem Pengendalian Intern Pemerintah Dan Standar Akuntansi Pemerintah Serta Implikasinya Pada Kualitas Laporan Keuangan Pemerintah Daerah, Simposium Nasional Akuntansi 18 Universitas Sumatera Utara, Medan

Pemerintah Provinsi Banten. 2016. Laporan Keterangan Pertanggungjawaban Gubernur Banten Akhir Tahun Anggaran 2015.

Rianse, Usman dan Abdi (2009), Metodologi Penelitian Sosial dan Ekonomi - Teori dan Aplikasi. Jakarta : Penerbit CV Alfabeta

Roviyantie, Devi. (2012). Pengaruh Kompetensi Sumber Daya Manusia dan Penerapan Sistem Akuntansi Keuangan Daerah Terhadap Kualitas Laporan Keuangan Daerah (Survei pada Organisasi Perangkat Daerah (OPD) Kabupaten Tasikmalaya). Jurnal Accounting. Vol.1 No.1

Subadriyah, Anita Rahayuningsih. (2015). Analisis Hubungan Kualitas Sumber Daya Manusia dan Kualitas Sistem Akuntansi Keuangan Daerah Dengan Kualitas Laporan Keuangan Pemerintah Daerah, Jurnal Ilmiah ISSN 2407-9189, FEB Universitas Islam Nahdlatul Ulama, Jepara

Sugiyono. (2016). Metode Penelitian Kombinasi (Mixed Methods). Bandung : Alfabeta

Suwanda, Dadang. (2015). Sistem Akuntansi Akrual Pemerintah Daerah Berpedoman SAP Berbasis Akrual. Jakarta : Penerbit PPM Manajemen.

Suwardjono. (2012). Teori Akuntansi Perekayasaan Pelaporan Keuangan. Yogyakarta : BPFE Yogyakarta.

Peraturan Perundang-undangan :

Keputusan Kepala BKN Nomor 46 A Tahun 2007 tentang Pedoman Penyusunan Standar Kompetensi Jabatan Struktural Pegawai Negeri Sipil

Peraturan Pemerintah Nomor 101 Tahun 2000 tentang Pendidikan dan Pelatihan Jabatan Pegawai Negeri Sipil

Peraturan Pemerintah Nomor 71 Tahun 2010 tentang Standar Akuntansi Pemerintahan. Jakarta : Penerbit CV.Novindo Pustaka Mandiri, 2011

Peraturan Menteri Dalam Negeri Nomor 64 Tahun 2013 tentang Penerapan Standar Akuntansi Pemerintahan Berbasis Akrual pada Pemerintah Daerah.

Press Release BPK RI Perwakilan Provinsi Banten, Penyerahan Laporan Hasil Pemeriksaan BPK atas Laporan Keuangan Pemerintah Provinsi Banten Tahun Anggaran 2015, melalui http://banten.bpk.go.id (10 Juni 2016) 